\title{
Warunki hydrogeochemiczne występowania wód siarczkowych w południowej części niecki miechowskiej
}

\author{
Ewelina Bąk ${ }^{1}$, Joanna Bruczyńska ${ }^{1}$, Iwona Lipiec ${ }^{1}$
}
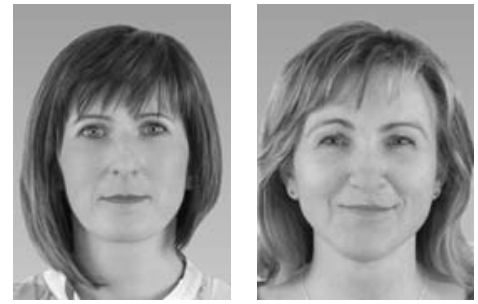

E. Bąk
J. Bruczyńska

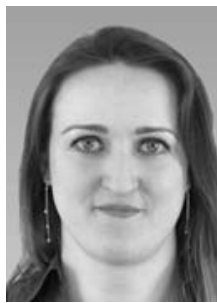

I. Lipiec

Hydrogeochemical conditions of sulphide waters in the southern part of the Miechów Basin. Prz. Geol., 69: 687-696; doi: 10.7306/2021.37

A b s tract. The paper presents the characteristics of sulphide waters in the Busko-Zdrój, Solec-Zdrój and Kazimierza Wielka area. The chemical composition was determined on the basis of results of analyses of groundwater samples from the B-4b Aleksander, B-8b Michat, B-13 Anna, B-16a Wiestawa, B-17 Ignacy, Busko C-1, Las Winiarski LW-1, Winiarski Forest LW-2, Cudzynowice GT-1, Solecki Shaft and Solec 2 Karol boreholes and the Gadawa (shaft), Szczerbaków (shaft) and Piestrzec springs. The following hydrochemical facies of sulphide waters were identified: $\mathrm{Cl}-\mathrm{Na}$, $\mathrm{Cl}-\mathrm{SO}_{4}-\mathrm{Na}$ and $\mathrm{SO}_{4}-\mathrm{Ca}$. Hydrogeochemical modelling allowed determining the saturation state of the water solution relative to the mineral phases of the reservoir rocks.

Keywords: sulphide waters, Miechów Basin, saturation index, hydrogeochemical modelling

W południowej części niecki miechowskiej, stanowiącej południowy fragment niecki szczecińsko-łódzko-miechowskiej (Stupnicka, 2007), występują wody siarczkowe. Według regionalizacji wód mineralnych i leczniczych są one zaliczane do wód wschodniej części zapadliska przedkarpackiego w prowincji karpackiej (Chowaniec i in., 2007). Ze względu na właściwości lecznicze wody te od dawna były znane i cenione. Dzięki urozmaiconemu składowi chemicznemu znalazły zastosowanie do leczenia wielu schorzeń, toteż stanowią obiekt badawczy o bardzo dużym znaczeniu poznawczym i utylitarnym.

W Prawie geologicznym i górniczym wody siarczkowe zostały zdefiniowane jako lecznicze wody podziemne zawierające co najmniej $1 \mathrm{mg} / \mathrm{dm}^{3}$ siarki dwuwartościowej (Ustawa, 2011). Siarka występuje w nich w postaci siarkowodoru $\left(\mathrm{H}_{2} \mathrm{~S}\right)$, jonu hydrosiarczkowego $\left(\mathrm{HS}^{-}\right)$ oraz wielosiarczków $\left(\mathrm{H}_{2} \mathrm{~S}_{\mathrm{x}}\right.$, przy czym $\mathrm{x}=2-6)$, a także $\mathrm{w}$ jonie tiosiarczanowym $\left(\mathrm{S}_{2} \mathrm{O}_{3}{ }^{2-}\right.$; Dowgiałło i in., 2002).

$\mathrm{W}$ artykule przedstawiono wyniki badań chemizmu i modelowania hydrogeochemicznego wód siarczkowych w

Ryc. 1. Lokalizacja obszaru badań na tle jednostek tektonicznych (wg Stupnickiej, 2007) Fig. 1. Location of research area with regard to tectonic units (after Stupnicka, 2007) utworach jury górnej, kredy górnej i miocenu niecki miechowskiej - w rejonie Buska-Zdroju, Solca-Zdroju oraz Kazimierzy Wielkiej (ryc. 1 i 2).

Badania składu chemicznego wód mineralnych południowej części niecki miechowskiej i przyległych partii

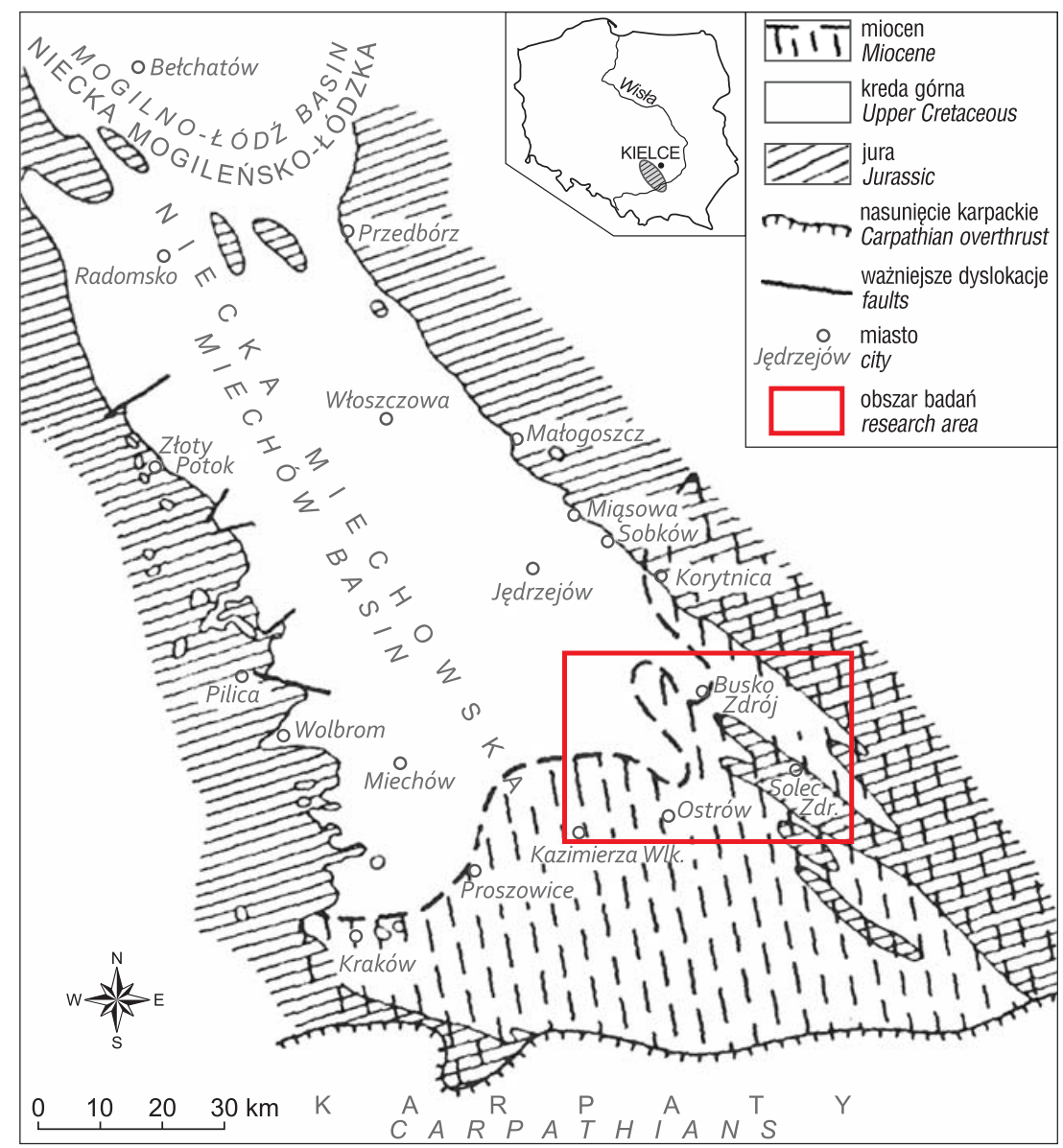

\footnotetext{
${ }^{1}$ Państwowy Instytut Geologiczny - Państwowy Instytut Badawczy, Oddział Świętokrzyski, ul. Zgoda 21, 25-953 Kielce; ewelina.bak@pgi.gov.pl; joanna.bruczynska@pgi.gov.pl; iwona.lipiec@pgi.gov.pl
} 


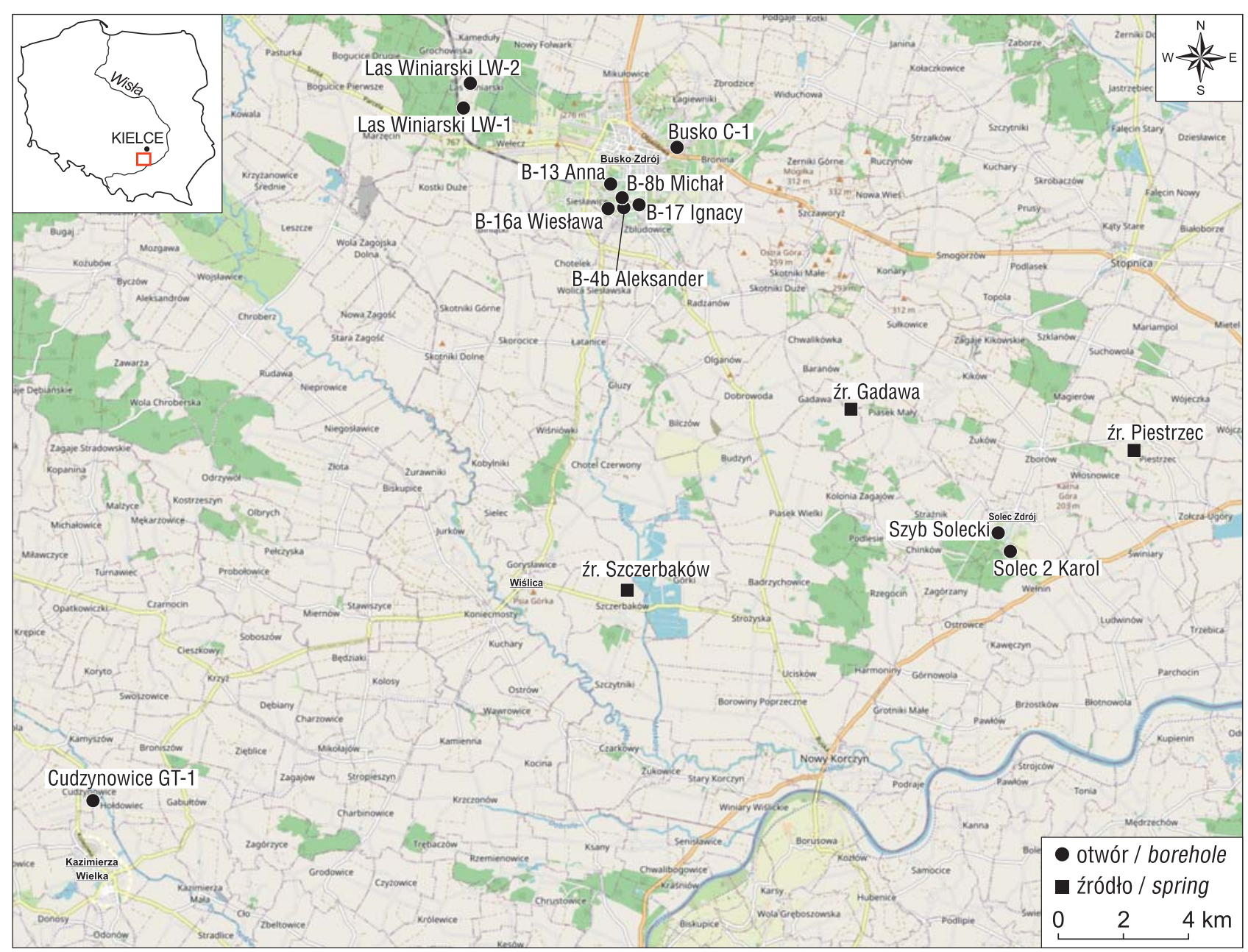

Ryc. 2. Lokalizacja poboru próbek wody do badań

Fig. 2. Location of water sampling sites for testing

zapadliska przedkarpackiego są prowadzone przede wszystkim w celu oceny ich przydatności w lecznictwie, a wyniki analiz są zapisywane głównie według formuły Kurłowa i przedstawiane w publikacjach i dokumentacjach hydrogeologicznych na diagramach Pipera, Schoellera lub Stiffa (Różkowski i in., 2006; Szczepański, Porwisz, 2007; Lipiec, 2009, 2015; Lisik, 2010; Migaszewski, 2010, 2013; Różkowski, Różkowski, 2010; Gała, 2013; Lisik, Szczepański, 2014, 2018; Chowaniec i in., 2015; Lipiec, Wiktorowicz, 2015a, b; Wątor, 2015; Wątor, Kmiecik, 2015; Wiktorowicz i in., 2015; Wiktorowicz, 2016; Gagulski i in., 2018; Wątor i in., 2019; Lipiec, Rusiniak, 2020). W ostatnich latach wzbogacono je także o badania specjacji siarki (Witczak, Świąder, 2010; Wątor, 2013; Lipiec, 2019). Nowym elementem badawczym jest także modelowanie hydrogeochemiczne, umożliwiające określenie stanu nasycenia wód podziemnych względem wybranych minerałów (Różkowski i in., 2011; Gała, 2011, 2012; Wątor, 2013; Lipiec, Wiktorowicz, 2015a; Lipiec, 2017a, b, 2019).

\section{OBSZAR BADAŃ}

Południowo-wschodnia część niecki miechowskiej, gdzie prowadzono badania, charakteryzuje się skomplikowaną budową geologiczną. Występują w niej struktury blokowo-fałdowe o kierunku NW-SE (ryc. 1), poprzecinane uskokami poprzecznymi oddzielającymi główne bloki tektoniczne, w obrębie których wyróżnia się jeszcze wiele mniejszych struktur (Stupnicka, 2007). Najstarszymi skałami, rozpoznanymi na tym obszarze, są łupki prekambryjskie. Na łupkach tych zalegają zerodowane utwory ordowiku, syluru, dewonu i karbonu oraz osady triasu i jury (Łyczewska, 1975). Na osadach jurajskich leżą piaski, wapienie margliste i margle kredowe, a ponad nimi mioceńskie osady ilasto-margliste oraz gipsy i anhydryty (Chowaniec i in., 2015).

W geologicznej historii niecki miechowskiej można wydzielić wiele cykli rozpoczynających się transgresją morza i sedymentacją osadów morskich oraz tworzeniem się w nich wód sedymentacyjnych. Obecny skład chemiczny wód podziemnych niecki jest efektem współczesnych warunków ich krążenia oraz we wcześniejszych cyklach hydrogeologicznych. Największy wpływ na ukształtowanie kontaktów hydraulicznych oraz skład chemiczny wód siarczkowych tego obszaru miały cykle hydrogeologiczne kredowy i neogeńsko-czwartorzędowy oraz ruchy górotwórcze orogenezy alpejskiej. W cenomanie na niemal całym obszarze niecki odbywała się sedymentacja piasków i piaskowców glaukonitowych (miąższość tych skał osiąga kilkadziesiąt metrów), na których osadzały się utwory ilasto-margliste z przewarstwieniami wapieni i piaskowców. Cykl kredowy zakończył się regresją morza górnokredowego podczas orogenezy alpejskiej. Kolejny 
cykl rozpoczęła transgresja morza mioceńskiego, w wyniku której osadziły się piaski, iły, wapienie, gipsy i anhydryty oraz zalegające na nich osady ilaste. Po ustąpieniu morza mioceńskiego rozpoczął się okres erozji, który trwa do dziś (Prażak, 2010).

Wody siarczkowe niecki miechowskiej występują w skałach górnokredowych: piaskach i piaskowcach z glaukonitem oraz w marglach i łupkach ilastych, a także w wapieniach jurajskich i wapieniach litotamniowych miocenu.

\section{METODYKA}

Prace badawcze poprzedzono inwentaryzacją danych archiwalnych dotyczących składu chemicznego i właściwości fizycznych wód siarczkowych w utworach jury górnej, kredy górnej i neogenu południowej części niecki miechowskiej. W wyniku analizy tych materiałów do poboru próbek wód do badań wytypowano 11 otworów wiertniczych oraz 3 źródła zlokalizowane w rejonie Buska-Zdroju, Solca-Zdroju i Kazimierzy Wielkiej (ryc. 2), drenujące neogeńskie, kredowe i jurajskie warstwy wodonośne. W latach 2018-2019 z tych 14 punktów pobrano próbki wód siarczkowych i wykonano ich polowe oraz laboratoryjne analizy fizykochemiczne. Podczas poboru próbek wody, ich utrwalania, przechowywania i transportu zachowano szczególną ostrożność, aby zabezpieczyć naturalne cechy fizykochemiczne wody.

Wskaźniki nietrwałe: temperaturę, $\mathrm{pH}$ i przewodność elektrolityczną właściwą (PEW), oznaczono in situ. Do badań terenowych wykorzystano pH-metr SLANDI SP300 $\mathrm{z}$ sondą $\mathrm{pH} / \mathrm{T}$, umożliwiający pomiar $\mathrm{pH}$ metodą potencjometryczną, oraz konduktometr SLANDI SC300 przeznaczony do pomiarów PEW metodą konduktometryczną, z elektrodą zintegrowaną z czujnikiem temperatury.

Laboratoryjne analizy próbek wody wykonano w Laboratorium Chemicznym PIG-PIB w Warszawie (cert. akr. PCA nr AB 283), a oznaczenia siarki (II) - w Laboratorium Badań Środowiskowych Przedsiębiorstwa Geologicznego Sp. z o.o. w Kielcach (cert. akr. PCA nr AB 1010). Zawartość siarki (II), mierzonąjako suma siarczków i siarkowodoru (w przeliczeniu na $\mathrm{H}_{2} \mathrm{~S}$ ), oznaczono metodą miareczkowo-jodometryczna. Wykonano tzw. duże analizy laboratoryjne wszystkich pobranych próbek wody, które objęły oznaczenie zawartości składników głównych (anionów: $\mathrm{Cl}^{-}, \mathrm{SO}_{4}{ }^{2-}, \mathrm{HCO}_{3}{ }^{-}, \mathrm{CO}_{3}{ }^{2-}$ oraz kationów: $\mathrm{Na}^{+}, \mathrm{Mg}^{2+}$, $\mathrm{Ca}^{2+}$ ), składników podrzędnych (anionów: $\mathrm{NO}_{3}^{-}, \mathrm{NO}_{2}^{-}$, $\mathrm{HPO}_{4}{ }^{2-}$ oraz kationów: $\left.\mathrm{NH}_{4}^{+}, \mathrm{K}^{+}, \mathrm{Fe}_{2}^{+}\right)$, a także mikroelementów (Ag, Al, As, B, Ba, Be, Br, Cd, Co, Cr, Cu, F, J, Li, $\mathrm{Mn}, \mathrm{Mo}, \mathrm{Ni}, \mathrm{Pb}, \mathrm{Sb}, \mathrm{Se}, \mathrm{Sn}, \mathrm{Sr}, \mathrm{Ti}, \mathrm{Tl}, \mathrm{U}, \mathrm{V}, \mathrm{Zn}$ oraz Si jako $\mathrm{SiO}_{2}$ ).

Wyniki analiz fizykochemicznych posłużyły do scharakteryzowania badanych wód siarczkowych według formuły Kurłowa (tab. 1) i przedstawienia na diagramie Pipera. Zmienność składu chemicznego tych wód oceniono na podstawie wyników badań przeprowadzonych w październiku 2019 r. Analizę składu chemicznego wód z wybranych 6 ujęć i 3 źródeł przedstawiono na diagramie Pipera (ryc. 3) oraz na diagramach promienistych Tickela (ryc. 4). Wykonano także analizę specjacyjną (ryc. 5 i 6) oraz modelowanie hydrogeochemiczne (tab. 2). Wyniki badań umożliwiły sporządzenie hydrogeochemicznej charakterystyki wód siarczkowych występujących w utworach: $\square$ kredy górnej - otwory Las Winiarski LW-1, Las Winiarski LW-2, Busko C-1, B-4b Aleksander, B-8b Michał, B-13 Anna, B-16a Wiesława, B-17 Ignacy, Szyb Solecki, Solec II Karol, Cudzynowice GT-1 oraz źródło Gadawa [szyb];

$\square$ jury górnej - źródło Szczerbaków;

$\square$ miocenu - źródło Piestrzec.

Formy występowania składników swoistych w wodach siarczkowych (specjacje) oraz stopień równowagi pomiędzy wodą a skałami zbiornikowymi oceniono na podstawie modelowania hydrogeochemicznego $\mathrm{z}$ wykorzystaniem programu PHREEQC v. $3.1 \mathrm{z}$ bazą danych wateq $4 f$ (Appelo, Postma, 2005; Parkhurst, Appelo, 2013). Modelowanie geochemiczne, określane jako obliczenia specjacyjne, jest popularną metodą oceny rzeczywistych form występowania składników w roztworach wodnych (Macioszczyk, 2006). W obliczeniach specjacyjnych istotną rolę odgrywa terenowy pomiar $\mathrm{pH}$ i Eh (potencjału utleniająco-redukcyjnego). W trakcie pomiarów Eh w terenie może jednak dojść do tzw. zatrucia elektrod, co prowadzi do uzyskania błędnych wyników (Whitfield, 1974). Program PHREEQC umożliwia stosunkowo wiarygodną ocenę Eh, polegająca na oznaczeniach siarki dwuwartościowej i siarki sześciowartościowej (Witczak, Świąder, 2010). W związku z tym także do wyliczenia Eh wykorzystano program PHREEQC.

Wyniki modelowania hydrogeochemicznego wykorzystano do określenia stanu nasycenia wód podziemnych względem wybranych minerałów na podstawie wskaźnika SI (saturation index), obliczonego według wzoru:

$$
S I=\lg \left[\frac{I A P}{K_{T}}\right]
$$

gdzie:

$I A P$ - iloczyn aktywności form obliczony na podstawie rzeczywistej aktywności w wodzie substancji biorących udział w reakcji;

$K_{T}$ - stała równowagi reakcji w danej temperaturze.

Wartości wskaźnika SI oscylujące wokół zera oznaczają stan równowagi chemicznej pomiędzy wodą a ośrodkiem skalnym. Dodatnie wartości wskaźnika SI świadczą o tendencji do wytrącania danej fazy mineralnej z roztworu wodnego (przesycenie wody względem minerału), ujemne zaś wskazują na możliwość jej rozpuszczania w wodzie (brak trwałości minerału) w odpowiednich warunkach termodynamicznych (Dobrzyński i in., 2018). Za stan bliski równowagi chemicznej przyjęto wartości wskaźnika SI zawierające się $\mathrm{w}$ przedziale $\pm 5 \% \log \mathrm{K}_{\mathrm{T}}$ (Appelo, Postma, 2005; Macioszczyk, Dobrzyński, 2002).

Skład mineralny utworów wodonośnych południowej części niecki miechowskiej określono na podstawie dostępnych danych literaturowych (Bzowska i in., 2011; Gała, 2012). Uwzględniając dominujące wykształcenie litologiczne warstw wodonośnych (piaskowce, wapienie, margle) do analizy wybrano: skalenie potasowe, albit, anortyt, kalcyt, dolomit, syderyt, kwarc, chalcedon, illit, kaolinit, muskowit, piryt i getyt. Gips, anhydryt i celestyn wzięto pod uwagę ze względu na występowanie poziomu gipsowego w osadach miocenu. Analizując wartości wyliczonego wskaźnika nasycenia SI, oceniono stan równowagi badanych wód siarczkowych względem minerałów 
obecnych w skałach wodonośnych południowej części niecki miechowskiej (tab. 2).

\section{WYNIKI BADAŃ}

\section{Charakterystyka hydrogeochemiczna wód siarczkowych}

W południowej części niecki miechowskiej wyróżniono trzy typy wód siarczkowych (tab. 1):

$\square$ chlorkowo-sodowe - odznaczające się największą mineralizacją, w zakresie od $11,5 \mathrm{mg} / \mathrm{dm}^{3}$ (Busko C-1) do 48,7 mg/dm³ (źródło Szczerbaków);

$\square$ chlorkowo-siarczanowo-sodowe - o mineralizacji w granicach $10,9 \mathrm{mg} / \mathrm{dm}^{3}$ (otwór Cudzynowice GT-1) do 17,9 (Szyb Solecki);

$\square$ siarczanowo-wapniowe - charakteryzujące się najmniejszą mineralizacja, w przedziale $2,3-2,4 \mathrm{mg} / \mathrm{dm}^{3}$ (źródło Piestrzec).
W składzie chemicznym wód źródła Szczerbaków zauważono wpływ ascenzji wód silnie zmineralizowanych. Najmniejszą mineralizacją odznaczają się wody poziomu mioceńskiego, największą zaś wody poziomu górnokredowego i górnojurajskiego. Wyniki analiz chemicznych ukazały duże podobieństwo wód poziomu górnokredowego. Reprezentują one głównie typ Cl-Na o zmiennej zawartości jonów siarczanowych. W wodach ujęć Cudzynowice GT-1 i Szyb Solecki oraz w źródle Gadawa występują wody typu $\mathrm{Cl}-\mathrm{SO}_{4}-\mathrm{Na}$, charakteryzujące się większym stężeniem jonów siarczanowych (ryc. 3 i 4).

\section{Rezultaty modelowania hydrogeochemicznego i analizy specjacyjnej}

We wszystkich badanych próbkach wód siarczkowych niecki miechowskiej dominowały dwie formy występowania siarki (II): $\mathrm{HS}^{-}$i $\mathrm{H}_{2} \mathrm{~S}$ (ryc. 5). Stanowiły one od $50 \%$ do

Tab. 1. Charakterystyka hydrogeochemiczna wód siarczkowych w południowej części niecki miechowskiej w latach 2018-2019

Tab. 1. Hydrogeochemical characteristics of sulphide waters in the southern part of the Miechów Basin

\begin{tabular}{|c|c|c|c|}
\hline $\begin{array}{l}\text { Punkty poboru próbek wody } \\
\text { Water sampling points }\end{array}$ & $\begin{array}{l}\text { Głębokość } \\
\text { ujętego poziomu } \\
\text { wodonośnego } \\
\text { [m p.p.t.] } \\
\text { Depth of the } \\
\text { exploited aquifer } \\
\text { [m b.g.l.] }\end{array}$ & $\begin{array}{c}\text { Typ hydrochemiczny } \\
\text { wody wg } \\
\text { Altowskiego-Szwieca } \\
\text { Hydrochemical type } \\
\text { of water according } \\
\text { to Altowski-Szwiec }\end{array}$ & $\begin{array}{c}\text { Charakterystyka skladu chemicznego wody } \\
\text { wg formuly Kurłowa } \\
\text { Characteristics of the chemical composition } \\
\text { of water according to the Kurlov formula }\end{array}$ \\
\hline otwór / borehole B-4b Aleksander & 19,5 & \multirow{10}{*}{$\mathrm{Cl}-\mathrm{Na}$} & $S^{23,0-29,0} M_{13,4-13,6} \frac{C l^{78-79} S_{4}^{19}}{N a^{81}} T^{12,0-12,7}$ \\
\hline otwór / borehole B-8b Michał & 26 & & $S^{42,5-45,1} M_{12,8} \frac{\mathrm{Cl}^{77-82} \mathrm{SO}_{4}^{17-18}}{N a^{81-82}} T^{11,1-12,6}$ \\
\hline otwór / borehole B-13 Anna & 30 & & $S^{45,1-46,7} M_{11,9-12,2} \frac{\mathrm{Cl}^{79-82} \mathrm{SO}_{4}^{18}}{\mathrm{Na}^{82} \mathrm{Mg}^{9-10}} T^{11,0-12,0}$ \\
\hline otwór / borehole B-16a Wiesława & 113 & & $S^{42,5-48,4} M_{12,9-13,2} \frac{C l^{79-80} S_{4}^{17-18}}{N a^{81}} T^{13,2-14,4}$ \\
\hline otwór / borehole B-17 Ignacy & 71 & & $S^{49,3-50,1} M_{13,6-13,7} \frac{\mathrm{Cl}^{79} \mathrm{SO}_{4}^{18-19}}{N a^{80-81}} T^{11,4-13,1}$ \\
\hline otwór / borehole Busko C-1 & 622,2 & & $S^{34,8-36,6} M_{11,5-11,8} \frac{C l^{80} S O_{4}^{16-17}}{N a^{86-87}} T^{23,5-23,6}$ \\
\hline otwór / borehole Las Winiarski LW-1 & 135,5 & & $S^{45,9-47,6} M_{12,2-12,3} \frac{\mathrm{Cl}^{80} \mathrm{SO}_{4}^{17}}{\mathrm{Na}^{82}} T^{12,8-13,5}$ \\
\hline otwór / borehole Las Winiarski LW-2 & 131 & & $S^{50,1-51,0} M_{12,5} \frac{\mathrm{Cl}^{79-80} \mathrm{SO}_{4}^{17-18}}{\mathrm{Na}^{74-83} \mathrm{Ca}^{15} \mathrm{Mg}^{10}} T^{12,5}$ \\
\hline otwór / borehole Solec 2 Karol & 98 & & $I^{12,6-13,2} S^{51,0-55,2} M_{21,3-21,6} \frac{\mathrm{Cl}^{80-81} \mathrm{SO}_{4}^{18-19}}{\mathrm{Na}^{76} \mathrm{Ca}^{11} \mathrm{Mg}^{12}} T^{14,3-15,2}$ \\
\hline źródło / spring Szczerbaków (szyb / shaft) & - & & $I^{3,19-16,7} S^{31,4} M_{18,3-48,7} \frac{C l^{90-91}}{\mathrm{Na}^{75-77} \mathrm{Ca}^{11-14} \mathrm{Mg}^{10}} T^{5,4-11,7}$ \\
\hline otwór / borehole Cudzynowice GT-1 & 667 & \multirow{3}{*}{$\mathrm{Cl}-\mathrm{SO}_{4}-\mathrm{Na}$} & $S^{98,6-107,0} M_{10,9-11,9} \frac{\mathrm{Cl}^{69-77} \mathrm{SO}_{4}^{28-38}}{\mathrm{Na}^{74-82} \mathrm{Ca}^{11-15} \mathrm{Mg}^{10}} T^{25,8^{*}}$ \\
\hline otwór / borehole Szyb Solecki & 120 & & $I^{10,6-10,7} S^{159-161} M_{17,6-17,9} \frac{\mathrm{Cl}^{75} \mathrm{SO}_{4}^{23}}{\mathrm{Na}^{74-75} \mathrm{Ca}^{15} \mathrm{Mg}^{10}} T^{13,8-14,8}$ \\
\hline źródło / spring Gadawa (szyb / shaft) & - & & $S^{8,5-9,35} M_{11,4-11,7} \frac{\mathrm{Cl}^{62-64} \mathrm{SO}_{4}^{33-34}}{\mathrm{Na}^{70} \mathrm{Ca}^{15-16} \mathrm{Mg}^{13-14}} T^{6,3-11,8}$ \\
\hline źródło / spring Piestrzec & - & $\mathrm{SO}_{4}-\mathrm{Ca}$ & $S^{10,2-16,1} M_{2,3-2,4} \frac{S O_{4}^{82-85} \mathrm{HCO}_{3}^{14-16}}{C a^{90-91}} T^{10,3-12,3}$ \\
\hline
\end{tabular}

* temperatura w trakcie wiercenia otworu w roku 2015 / temperature during the drilling of the borehole in the year 2015 


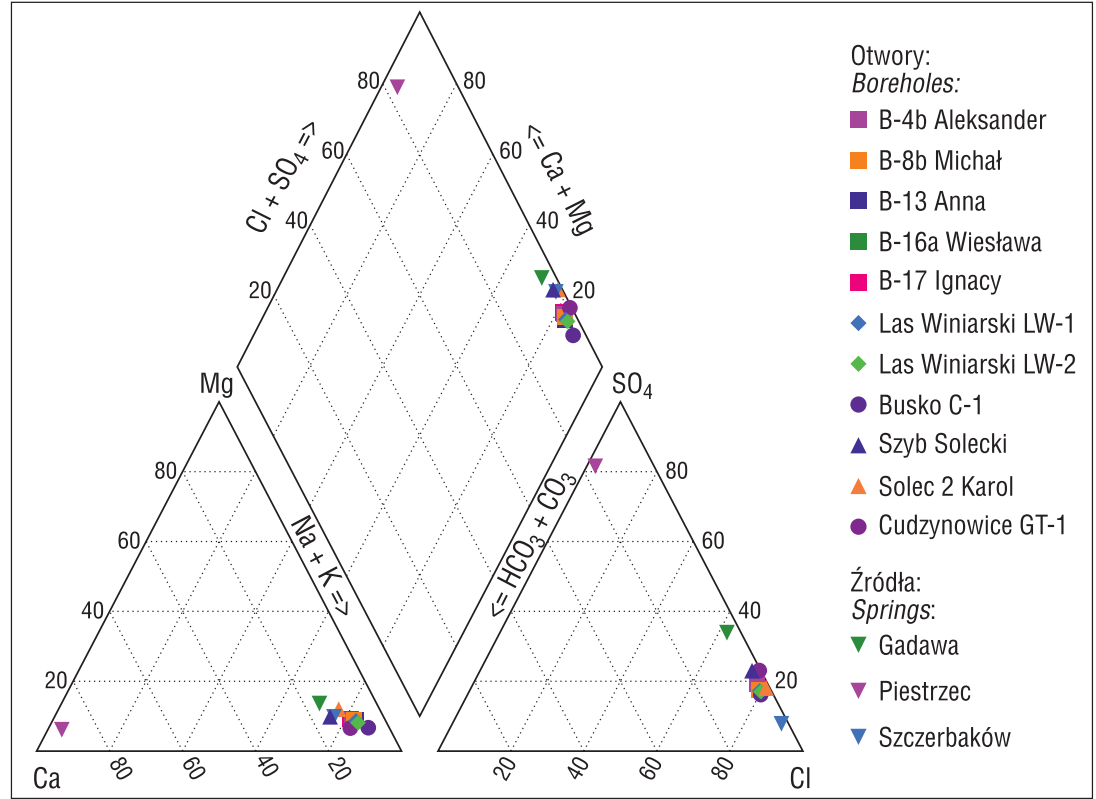

Ryc. 3. Skład chemiczny badanych wód na diagramie Pipera

Fig. 3. Chemical composition of tested waters in the Piper diagram

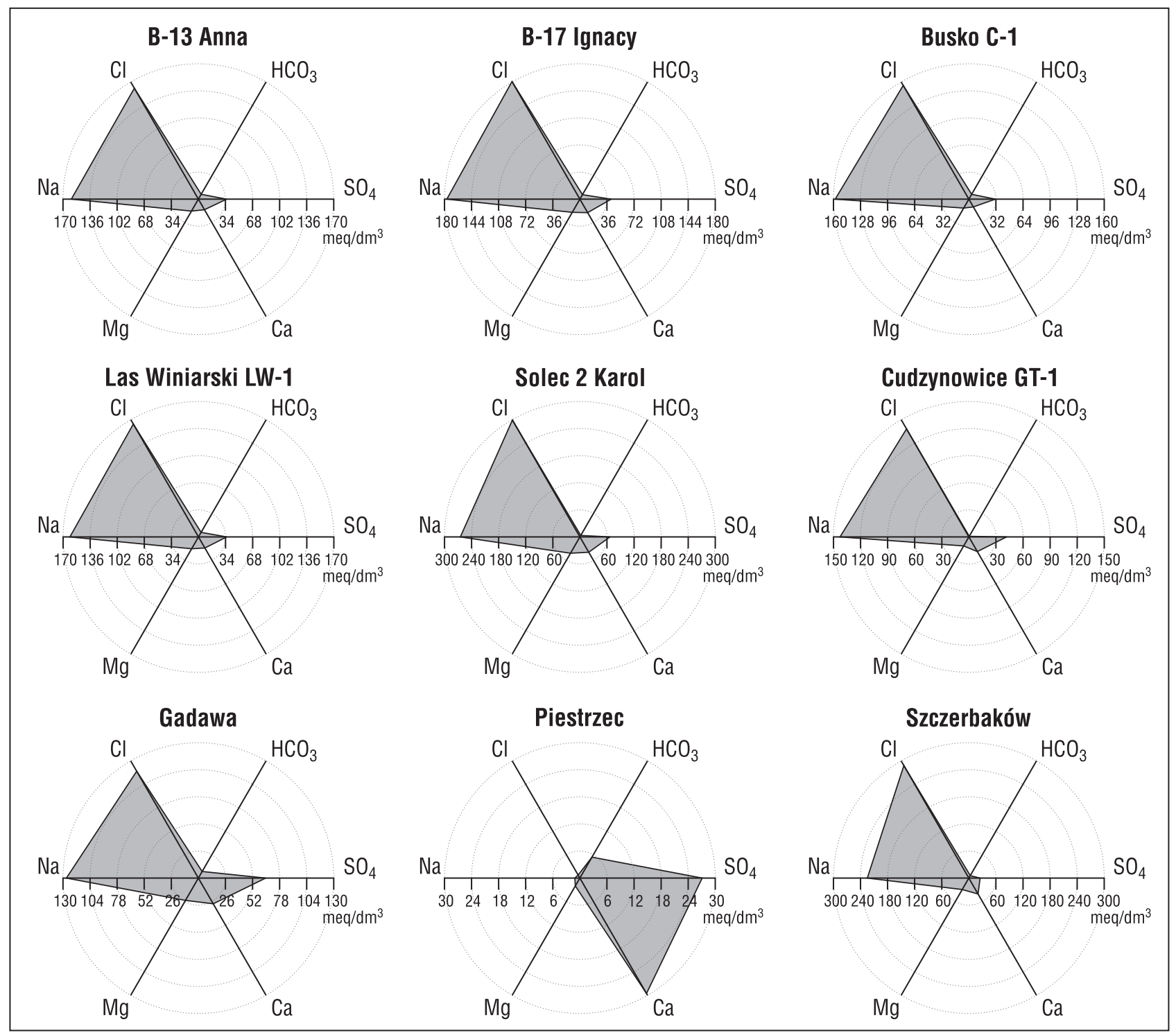

$84 \%\left(\mathrm{HS}^{-}\right)$oraz od $14 \%$ do $49 \%\left(\mathrm{H}_{2} \mathrm{~S}\right)$ wszystkich specjacji siarki dwuwartościowej. Udział pozostałych form nie przekraczał 0,9\%. Siarka (VI) występowała przeważnie $\mathrm{w}$ postaci: $\mathrm{SO}_{4}{ }^{2-}$, $\mathrm{NaSO}_{4}^{-}, \mathrm{MgSO}_{4}$ oraz $\mathrm{CaSO}_{4}$ (ryc. 6). $\mathrm{W}$ procentowym składzie jonowym badanych wód udział tych form był następujący: $60-70 \% \quad \mathrm{SO}_{4}^{2-}, 11-17 \%$ $\mathrm{NaSO}_{4}^{-}, 7-13 \% \quad \mathrm{MgSO}_{4}$ oraz $5-10 \%$ $\mathrm{CaSO}_{4}$. Wyjątek stanowiła woda ze źródła Piestrzec, charakteryzująca się zdecydowanie mniejszym stężeniem $\mathrm{MgSO}_{4} \mathrm{i} \mathrm{CaSO}_{4}$, wynoszącym odpowiednio $2 \%$ i $0,2 \%$. Udział pozostałych specjacji siarki (VI) kształtował się poniżej $0,4 \%$. Występowanie poszczególnych specjacji siarki (II) w wodach siarczkowych przedstawiono w zakresie powyżej $10^{-8} \mathrm{~mol} / \mathrm{dm}^{3}$, natomiast siarki (VI) powyżej $10^{-9} \mathrm{~mol} / \mathrm{dm}^{3}$.
Cudzynowice GT-1

Szczerbaków

Ryc. 4. Skład chemiczny wybranych ujęć oraz naturalnych wypływów wód siarczkowych na wykresach Tickela

Fig. 4. Chemical composition of selected intakes and natural outflows of sulphide waters in Tickel's charts 


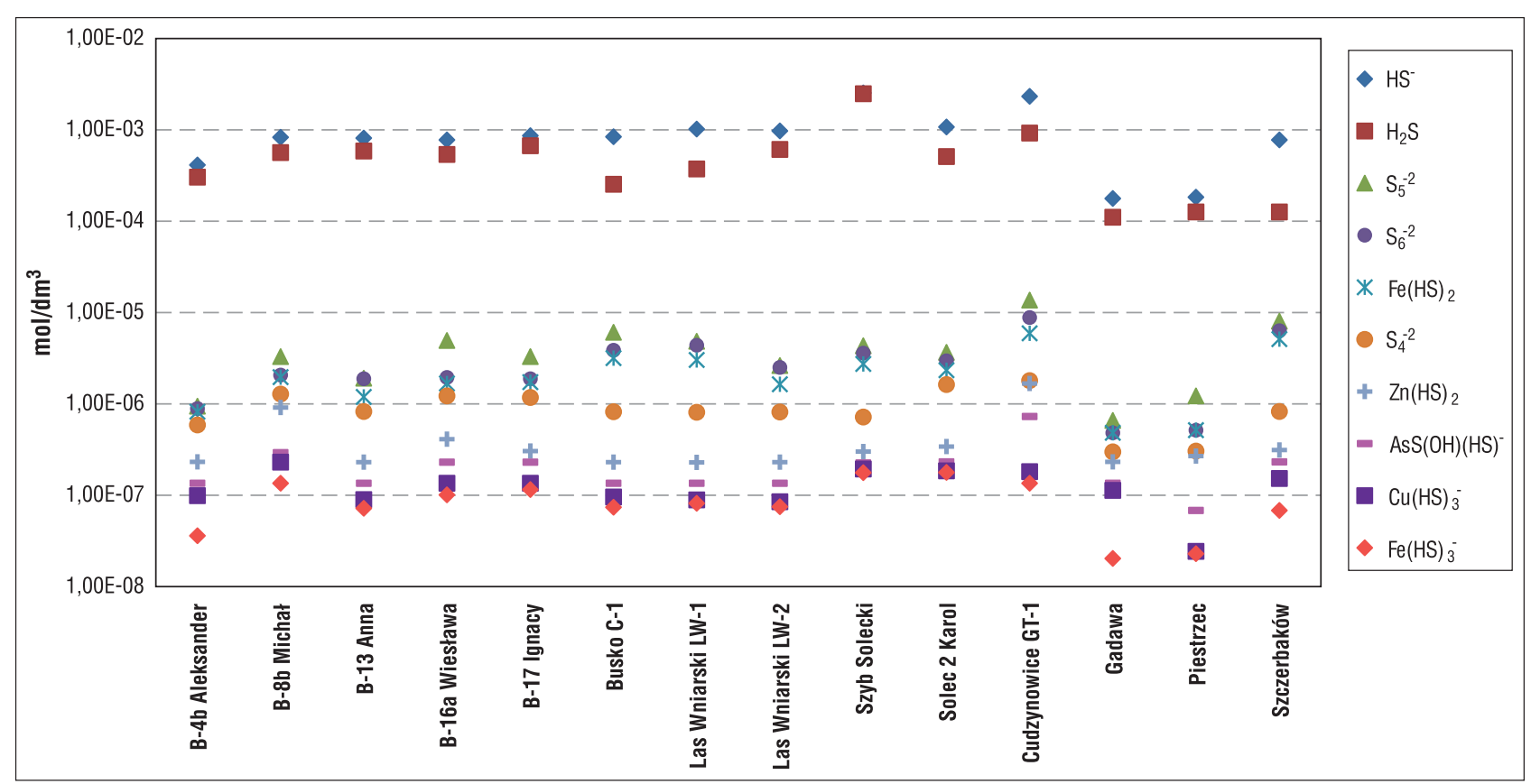

Ryc. 5. Występowanie specjacji siarki (II) w wodach siarczkowych w południowej części niecki miechowskiej Fig. 5. Occurrence of sulphur speciation (II) in sulphide waters in the southern part of the Miechów Basin

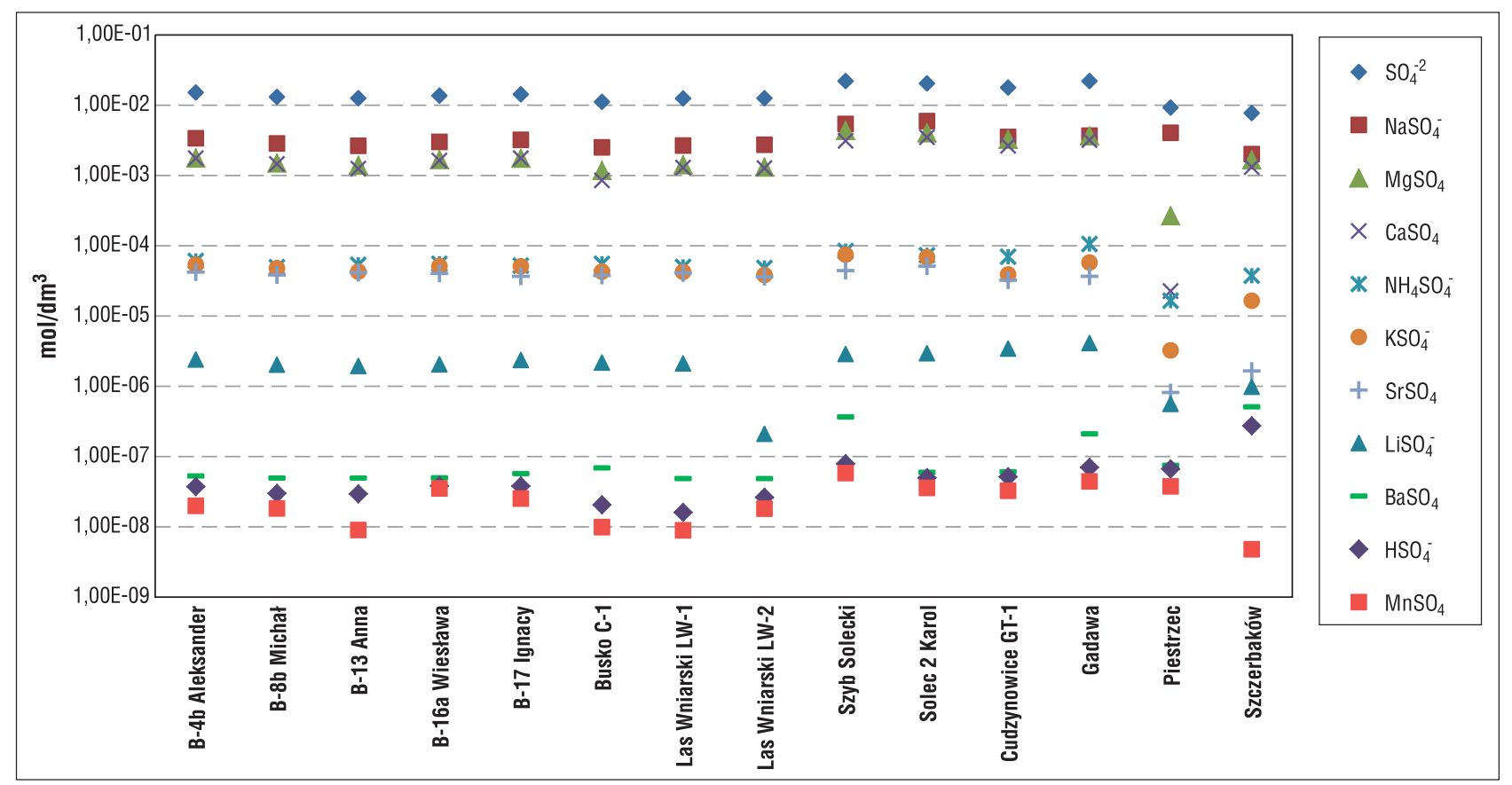

Ryc. 6. Występowanie specjacji siarki (VI) w wodach siarczkowych w południowej części niecki miechowskiej Fig. 6. Occurrence of sulphur speciation (VI) in sulphide waters in the southern part of the Miechów Basin

Ustalono, że na obszarze niecki miechowskiej wody poziomu kredowego pozostają przeważnie w stanie równowagi z albitem, skaleniami potasowymi, kalcytem, dolomitem, chalcedonem oraz celestynem. Sa one natomiast przesycone względem kwarcu, muskowitu, kaolinitu i pirytu. Na możliwość rozpuszczania w wodzie wskazują ujemne wartości wskaźnika SI względem anortytu, syderytu, anhydrytu i getytu. W odniesieniu do gipsu wskaźniki SI wód poziomu kredowego przyjmują zarówno wartości ujemne, jak i z zakresu odpowiadającego stanowi równowagi. Świadczy to o tym, że gips na pewno nie będzie się wytrącał z roztworu, może się natomiast $\mathrm{w}$ nim rozpuszczać.
Wody poziomu neogeńskiego, reprezentowane przez źródło Piestrzec, pozostają w stanie równowagi hydrogeochemicznej względem skaleni potasowych, dolomitu, gipsu i illitu. Przesycenie względem kalcytu, kwarcu, chalcedonu, muskowitu, kaolinitu i pirytu wskazuje na możliwość wytrącania się tych minerałów z roztworu. Względem albitu, anortytu, syderytu, anhydrytu, celestynu i getytu wartości wskaźnika SI kształtują się znacznie poniżej przedziału określającego stan równowagi.

Wody siarczkowe poziomu jurajskiego (źródło Szczerbaków) pozostają w stanie równowagi hydrogeochemicznej jedynie względem kwarcu i illitu, są natomiast 
Tab. 2. Wartości wskaźnika $S I$ wybranych faz mineralnych w wodach siarczkowych południowej części niecki miechowskiej

Table 2. SI index values of selected mineral phases in sulphide waters in the southern part of the Miechów Basin

\begin{tabular}{|c|c|c|c|c|c|c|c|c|c|c|c|c|c|c|c|}
\hline \multirow{4}{*}{ 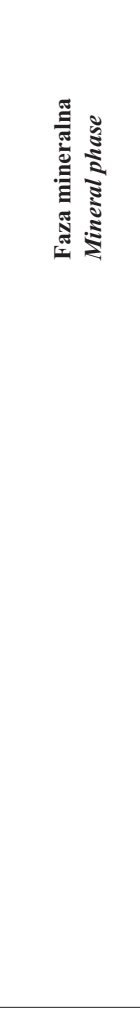 } & \multirow{4}{*}{ 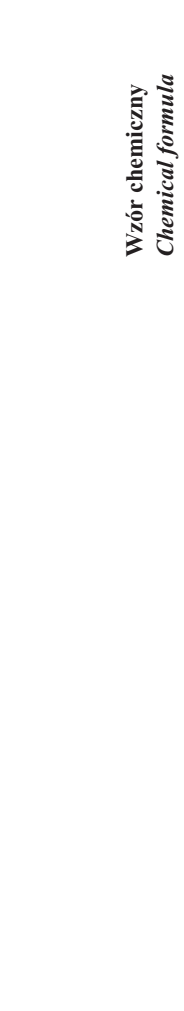 } & \multicolumn{14}{|c|}{ Litologia i wiek warstw wodonośnych / Lithology and age of aquifers } \\
\hline & & \multicolumn{3}{|c|}{ 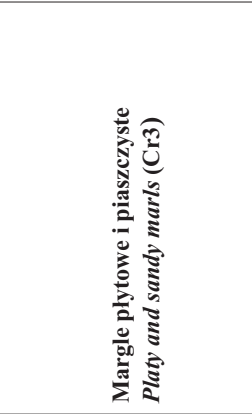 } & \multicolumn{2}{|c|}{ 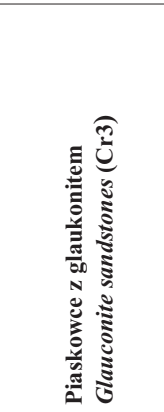 } & \multicolumn{3}{|c|}{ 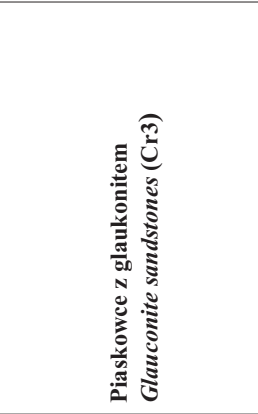 } & \multirow{2}{*}{ 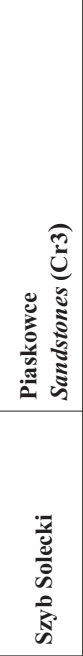 } & \multirow{2}{*}{ 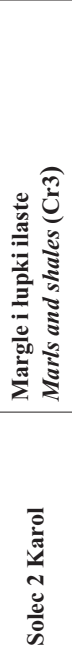 } & \multirow{2}{*}{ 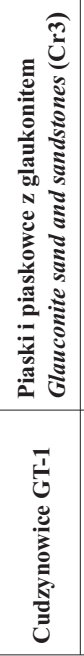 } & \multirow{2}{*}{ 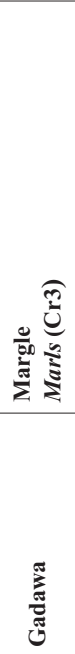 } & \multirow{2}{*}{ 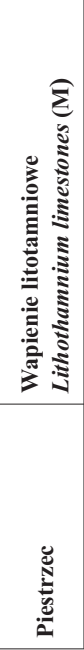 } & \multirow{2}{*}{ 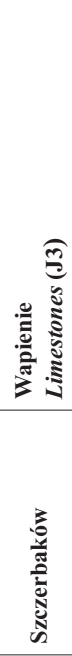 } \\
\hline & & 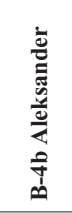 & 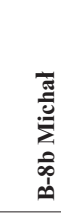 & $\begin{array}{l}\frac{\pi}{4} \\
\frac{m}{a} \\
\frac{m}{n}\end{array}$ & 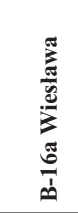 & 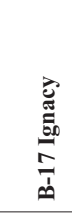 & 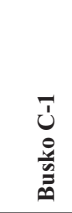 & 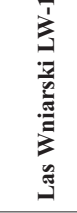 & 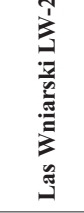 & & & & & & \\
\hline & & \multicolumn{14}{|c|}{$\begin{array}{l}\text { Wartość wskaźnika nasycenia (SI) } \\
\text { Value of Saturation Index } \pm 5 \% \log \mathrm{K}_{\mathrm{T}}\end{array}$} \\
\hline \multirow{2}{*}{$\begin{array}{l}\text { Skalenie } \mathrm{K} \\
\text { K-feldspars }\end{array}$} & \multirow{2}{*}{$\mathrm{K}\left[\mathrm{AlSi}_{3} \mathrm{O}_{8}\right]$} & 0,98 & 0,32 & 0,19 & 0,42 & 0,12 & $-0,45$ & 0,18 & 0,52 & 1,71 & 0,51 & $-0,63$ & 1,03 & 0,33 & $-1,26$ \\
\hline & & $\pm 1,10$ & $\pm 1,1$ & $\pm 1,08$ & $\pm 1,07$ & $\pm 1,08$ & $\pm 1,03$ & $\pm 1,07$ & $\pm 1,08$ & $\pm 1,07$ & $\pm 1,07$ & $\pm 1,02$ & $\pm 1,08$ & $\pm 1,08$ & $\pm 1,07$ \\
\hline \multirow{2}{*}{$\begin{array}{l}\text { Albit } \\
\text { Albite }\end{array}$} & \multirow{2}{*}{$\mathrm{Na}\left[\mathrm{AlSi}_{3} \mathrm{O}_{8}\right]$} & 0,14 & $-0,5$ & $-0,68$ & $-0,43$ & $-0,71$ & $-1,13$ & $-0,72$ & $-0,37$ & 0,97 & $-0,14$ & $-1,31$ & 0,18 & $-1,48$ & $-2,11$ \\
\hline & & $\pm 0,93$ & $\pm 0,9$ & $\pm 0,94$ & $\pm 0,94$ & $\pm 0,94$ & $\pm 0,91$ & $\pm 0,94$ & $\pm 0,94$ & $\pm 0,93$ & $\pm 0,93$ & $\pm 0,89$ & $\pm 0,94$ & $\pm 0,94$ & $\pm 0,93$ \\
\hline \multirow{2}{*}{$\begin{array}{l}\text { Anortyt } \\
\text { Anorthite }\end{array}$} & \multirow{2}{*}{$\mathrm{Ca}\left[\mathrm{Al}_{2} \mathrm{Si}_{2} \mathrm{O}_{8}\right]$} & $-3,45$ & $-4,4$ & $-4,64$ & $-4,36$ & $-4,59$ & $-4,86$ & $-4,56$ & -4 & $-1,75$ & $-3,6$ & $-4,53$ & $-3,16$ & $-3,25$ & $-5,15$ \\
\hline & & $\pm 1,00$ & $\pm 1,0$ & $\pm 1,00$ & $\pm 1,00$ & $\pm 1,00$ & $\pm 0,99$ & $\pm 1,00$ & $\pm 1,00$ & $\pm 1,00$ & $\pm 1,00$ & $\pm 0,98$ & $\pm 1,01$ & $\pm 1,01$ & $\pm 0,10$ \\
\hline \multirow{2}{*}{$\begin{array}{l}\text { Kalcyt } \\
\text { Calcite }\end{array}$} & \multirow{2}{*}{$\mathrm{CaCO}_{3}$} & 0,05 & 0,05 & $-0,01$ & 0,06 & 0,04 & 0,18 & 0,26 & $-0,01$ & 0,05 & 0,06 & 0,27 & 0,34 & 0,48 & 0,91 \\
\hline & & $\pm 0,42$ & $\pm 0,4$ & $\pm 0,42$ & $\pm 0,42$ & $\pm 0,42$ & $\pm 0,42$ & $\pm 0,42$ & $\pm 0,42$ & $\pm 0,42$ & $\pm 0,42$ & $\pm 0,42$ & $\pm 0,42$ & $\pm 0,42$ & $\pm 0,42$ \\
\hline \multirow{2}{*}{$\begin{array}{l}\text { Dolomit } \\
\text { Dolomite }\end{array}$} & \multirow{2}{*}{$\mathrm{Ca}, \mathrm{Mg}\left(\mathrm{CO}_{3}\right)_{2}$} & 0,09 & 0,08 & 0 & 0,12 & 0,05 & 0,56 & 0,53 & $-0,04$ & $-0,06$ & 0,18 & 0,53 & 0,57 & $-0,24$ & 1,71 \\
\hline & & $\pm 0,84$ & $\pm 0,8$ & $\pm 0,84$ & $\pm 0,84$ & $\pm 0,84$ & $\pm 0,85$ & $\pm 0,84$ & $\pm 0,84$ & $\pm 0,84$ & $\pm 0,84$ & $\pm 0,86$ & $\pm 0,84$ & $\pm 0,84$ & $\pm 0,84$ \\
\hline \multirow{2}{*}{$\begin{array}{l}\text { Syderyt } \\
\text { Siderite }\end{array}$} & \multirow{2}{*}{$\mathrm{FeCO}_{3}$} & $-2,81$ & $-2,8$ & $-3,46$ & $-2,64$ & $-2,95$ & $-3,11$ & $-3,4$ & $-3,63$ & $-4,75$ & $-3,58$ & $-4,32$ & $-2,11$ & $-2,05$ & $-2,84$ \\
\hline & & $\pm 0,54$ & $\pm 0,5$ & $\pm 0,54$ & $\pm 0,54$ & $\pm 0,54$ & $\pm 0,54$ & $\pm 0,54$ & $\pm 0,54$ & $\pm 0,54$ & $\pm 0,54$ & $\pm 0,55$ & $\pm 0,54$ & $\pm 0,54$ & $\pm 0,54$ \\
\hline \multirow[t]{2}{*}{$\begin{array}{l}\text { Kwarc } \\
\text { Quartz }\end{array}$} & \multirow{4}{*}{$\mathrm{SiO}_{2}$} & 0,51 & 0,43 & 0,39 & 0,48 & 0,37 & 0,29 & 0,36 & 0,38 & 0,55 & 0,41 & 0,28 & 0,55 & 0,79 & $-0,13$ \\
\hline & & $\pm 0,21$ & $\pm 0,2$ & $\pm 0,21$ & $\pm 0,21$ & $\pm 0,21$ & $\pm 0,20$ & $\pm 0,21$ & $\pm 0,21$ & $\pm 0,21$ & $\pm 0,21$ & $\pm 0,20$ & $\pm 0,21$ & $\pm 0,21$ & $\pm 0,21$ \\
\hline \multirow{2}{*}{$\begin{array}{l}\text { Chalcedon } \\
\text { Chalcedony }\end{array}$} & & 0,04 & $-0,0$ & $-0,08$ & 0,01 & $-0,09$ & $-0,14$ & $-0,1$ & $-0,09$ & 0,09 & $-0,05$ & $-0,14$ & 0,08 & 0,32 & $-0,59$ \\
\hline & & $\pm 0,19$ & $\pm 0,1$ & $\pm 0,19$ & $\pm 0,18$ & $\pm 0,19$ & $\pm 0,18$ & $\pm 0,18$ & $\pm 0,19$ & $\pm 0,18$ & $\pm 0,18$ & $\pm 0,18$ & $\pm 0,19$ & $\pm 0,19$ & $\pm 0,18$ \\
\hline \multirow{2}{*}{$\begin{array}{l}\text { Gips } \\
\text { Gypsum }\end{array}$} & $\mathrm{CH} \mathrm{CO} \times 2 \mathrm{H}$ & $-0,4$ & $-0,4 \varepsilon$ & $-0,55$ & $-0,44$ & $-0,4$ & $-0,77$ & $-0,54$ & $-0,54$ & $-0,01$ & $-0,1$ & $-0,2$ & $-0,08$ & $-0,05$ & $-0,43$ \\
\hline & $\mathrm{CaSO}_{4} \times 2 \mathrm{H}_{2} \mathrm{O}$ & $\pm 0,23$ & $\pm 0,2$. & $\pm 0,23$ & $\pm 0,23$ & $\pm 0,23$ & $\pm 0,23$ & $\pm 0,23$ & $\pm 0,23$ & $\pm 0,23$ & $\pm 0,23$ & $\pm 0,23$ & $\pm 0,23$ & $\pm 0,23$ & $\pm 0,23$ \\
\hline Anhydryt & & $-0,65$ & $-0,73$ & $-0,79$ & $-0,69$ & $-0,65$ & $-0,99$ & $-0,78$ & $-0,79$ & $-0,25$ & $-0,34$ & $-0,4$ & $-0,33$ & $-0,3$ & $-0,67$ \\
\hline & & $\pm 0,22$ & $\pm 0,2$ & $\pm 0,22$ & $\pm 0,22$ & $\pm 0,22$ & $\pm 0,22$ & $\pm 0,22$ & $\pm 0,22$ & $\pm 0,22$ & $\pm 0,22$ & $\pm 0,22$ & $\pm 0,22$ & $\pm 0,22$ & $\pm 0,22$ \\
\hline
\end{tabular}


Tab. 3. Wyniki badań specjacji siarki w otworze Las Winiarski LW-1 w latach 2010-2019

Table 3. Results of sulphur speciation studies in the Las Winiarski LW-1 borehole over the years 2010-2019

\begin{tabular}{|c|c|c|c|c|c|}
\hline \multicolumn{6}{|c|}{ Specjacje siarki w wodzie $\mathrm{z}$ ujęcia Las Wniarski LW-1 / Sulphur speciations of water from the Las Wniarski LW-1 intake $\left[\mathrm{mmol} / \mathrm{kgH}_{2} \mathrm{O}\right]$} \\
\hline \multicolumn{2}{|r|}{$\begin{array}{l}\text { Specjacje } \\
\text { Speciations }\end{array}$} & Witczak, Świąder (2010) & Wątor (2013) & Lipiec (2019) & $\begin{array}{c}\text { Badania wlasne w } 2019 \mathrm{r} . \\
\text { Own study in } 2019\end{array}$ \\
\hline \multirow{10}{*}{ 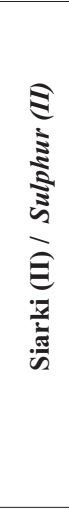 } & $\mathrm{S}^{(-2)}$ & 0,759 & 1,24 & 1,407 & 1,45 \\
\hline & $\mathrm{HS}^{-}$ & 0,452 & 0,825 & 0,771 & 1,01 \\
\hline & $\mathrm{H}_{2} \mathrm{~S}$ & 0,288 & 0,369 & 0,612 & 0,37 \\
\hline & $\mathrm{S}_{5}^{-2}$ & 0,001 & 0,003 & 0,002 & 0,005 \\
\hline & $\mathrm{S}_{6}^{-2}$ & 0,001 & 0,003 & 0,002 & 0,004 \\
\hline & $\mathrm{S}_{4}^{-2}$ & 0,001 & 0,002 & 0,001 & 0,003 \\
\hline & $\mathrm{Fe}(\mathrm{HS})_{2}$ & 0,0002 & 0,001 & 0 & 0,001 \\
\hline & $\mathrm{Zn}(\mathrm{HS})_{2}$ & $1,57 \mathrm{E}-06$ & b.d. & b.d. & $2,29 \mathrm{E}-04$ \\
\hline & AsS $(\mathrm{OH})(\mathrm{HS})^{-}$ & b.d. & b.d. & b.d. & $1,35 \mathrm{E}-04$ \\
\hline & $\mathrm{Fe}(\mathrm{HS})_{3}{ }^{-}$ & $9,36 \mathrm{E}-06$ & b.d. & b.d. & $8,85 \mathrm{E}-05$ \\
\hline \multirow{12}{*}{ 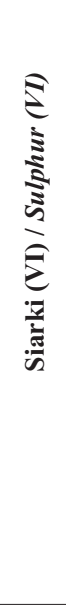 } & $\mathrm{S}_{(6)}$ & 10,32 & b.d. & 16,41 & 17,9 \\
\hline & $\mathrm{SO}_{4}^{-2}$ & 7,043 & b.d. & 11,12 & 12,4 \\
\hline & $\mathrm{NaSO}_{4}^{-}$ & 1,374 & b.d. & 2,431 & 2,65 \\
\hline & $\mathrm{MgSO}_{4}$ & 1,021 & b.d. & 1,395 & 1,41 \\
\hline & $\mathrm{CaSO}_{4}$ & 0,785 & b.d. & 1,338 & 1,29 \\
\hline & $\mathrm{NH}_{4} \mathrm{SO}_{4}^{-}$ & 0,029 & b.d. & 0,036 & 0,05 \\
\hline & $\mathrm{KSO}_{4}^{-}$ & 0,039 & b.d. & 0,051 & 0,042 \\
\hline & $\mathrm{SrSO}_{4}$ & 0,025 & b.d. & 0,039 & 0,041 \\
\hline & $\mathrm{LiSO}_{4}^{-}$ & 0 & b.d. & 0,002 & 0,002 \\
\hline & $\mathrm{BaSO}_{4}$ & $3,72 \mathrm{E}-05$ & b.d. & b.d. & $4,86 \mathrm{E}-05$ \\
\hline & $\mathrm{HSO}_{4}^{-}$ & $1,49 \mathrm{E}-05$ & b.d. & b.d. & $1,61 \mathrm{E}-05$ \\
\hline & $\mathrm{MnSO}_{4}$ & $8,21 \mathrm{E}-06$ & b.d. & b.d. & $8,92 \mathrm{E}-06$ \\
\hline \multicolumn{2}{|c|}{$\begin{array}{l}\text { Sposób określenia Eh } \\
\text { Method of specifying Eh }\end{array}$} & $\begin{array}{l}\text { program PHREEQC } \\
\mathrm{S}^{(-2)} / \mathrm{S}^{(6)}\end{array}$ & $\begin{array}{l}\text { program PHREEQC } \\
\mathrm{S}^{(-2)} / \mathrm{S}^{(6)}\end{array}$ & $\begin{array}{l}\text { pomiar terenowy } \\
\text { field measurement }\end{array}$ & $\begin{array}{l}\text { program PHREEQC } \\
\mathrm{S}^{(-2)} / \mathrm{S}^{(6)}\end{array}$ \\
\hline
\end{tabular}

Objaśnienia / Explanations: b.d. - brak danych / data not available

przesycone względem kalcytu, dolomitu, muskowitu, kaolinitu i pirytu. Wartość wskaźnika nasycenia SI pozostałych faz mineralnych jest ujemna (tab. 2). Wszystkie analizowane wody siarczkowe są przesycone względem muskowitu, kaolinitu i pirytu.

Przesycenie roztworu wodnego fazami mineralnymi świadczy o możliwości ich wytrącania (Tomaszewska, 2008). W zależności od specyfiki mineralnej skał zbiornikowych, warunków redox (Eh), temperatury oraz $\mathrm{pH}$ istnieje możliwość prognozowania wytrącania minerałów wtórnych w instalacjach ujmujących wody siarczkowe. Ocena warunków utleniająco-redukcyjnych dokonana na podstawie wskaźnika $r H$ (Merkel, Sperling, 1996) wykazała, że na analizowanym obszarze w wodach siarczkowych panują warunki słabo redukcyjne ( $r H$ w zakresie od 13,8 do 15,3). W warunkach eksploatacji otworu LW-1 zauważa się wzrost w czasie zawartości badanych składników (tab. 3).

\section{DYSKUSJA WYNIKÓW}

Obliczenia specjacyjne prowadzą do uzyskania pełniejszego modelu roztworu niż klasyczne metody analityczne, które w większości ograniczają się do pomiaru całkowitego stężenia badanego składnika. Szczególnie istotna jest znajomość form występowania składników mineralnych w wodach leczniczych, ponieważ często decydują one o biodostępności oraz farmakologicznym działaniu związków chemicznych (Selinus i in., 2005).

Wyniki modelowania hydrogeochemicznego w znacznym stopniu zależą od wartości Eh, którą trudno jest zmierzyć w terenie. W związku z tym, wzorując się na metodach badań stosowanych przez innych autorów, Eh przyjęto na podstawie oznaczeń analitycznych siarki dwuwartościowej, oznaczonej w analizie jako $\mathrm{H}_{2} \mathrm{~S}$, i siarki sześciowartościowej, oznaczonej jako siarczany (Witczak, Świąder, 2010). Uzyskane wyniki badań są zbliżone do znanych z literatury (Witczak, Świąder, 2010; Wątor, 2013; Lipiec, 2019). Przykładem są między innymi analizy specjacji siarki i wyniki modelowania hydrogeochemicznego w otworze Las Winiarski LW-1 (tab. 3 i 4).

\section{PODSUMOWANIE}

Wody siarczkowe południowej części niecki miechowskiej występują w wapieniach litotamniowych neogenu, marglach, łupkach, piaskach i piaskowcach kredy górnej oraz górnojurajskich wapieniach. Są to głównie wody chlorkowo-sodowe, w mniejszym stopniu chlorkowo-siarczanowo-sodowe oraz sporadycznie siarczanowo-wapnio- 
Tab. 4. Stan równowagi wód siarczkowych względem poszczególnych faz mineralnych

Tab. 4. Equilibrium state of sulphide waters in relation to individual mineral phases

\begin{tabular}{|c|c|c|c|}
\hline \multicolumn{4}{|c|}{$\begin{array}{l}\text { Wody siarczkowe } \mathrm{z} \text { ujęcia Las Winiarski LW-1 } \\
\text { sulphide waters from the Las Winiarski } L W-1 \text { intake }\end{array}$} \\
\hline $\begin{array}{l}\text { Faza mineralna } \\
\text { Mineral phase }\end{array}$ & Wątor (2013) & Lipiec (2019) & $\begin{array}{l}\text { Badania wlasne } \\
\text { Own study }\end{array}$ \\
\hline Skalenie K / K feldspars & b.d. & $=$ & $=$ \\
\hline Albit / Albite & $=$ & $=$ & $=$ \\
\hline Anortyt / Anorthite & - & - & - \\
\hline Kalcyt / Calcite & $=$ & $=$ & $=$ \\
\hline Dolomit / Dolomite & $=$ & $=$ & $=$ \\
\hline Syderyt / Siderite & - & b.d. & - \\
\hline Kwarc / Quartz & + & + & + \\
\hline Chalcedon / Chalcedony & $=$ & $=$ & $=$ \\
\hline Gips / Gypsum & - & - & - \\
\hline Anhydryt / Anhydrite & b.d. & - & - \\
\hline Celestyn / Celestine & b.d. & $=$ & $=$ \\
\hline Illit / Illite & b.d. & $=$ & $=$ \\
\hline Muskowit / Muscovite & b.d. & + & + \\
\hline Kaolinit / Kaolinite & + & + & + \\
\hline Piryt / Pyrite & + & + & + \\
\hline Getyt / Goethite & - & b.d. & - \\
\hline
\end{tabular}

Objaśnienia / Explanations: = stan równowagi / equilibrium state; - stan niedosycenia / undersaturation state;

+ stan przesycenia / supersaturation state; b.d. - brak danych / no data

we. Na podstawie wyników badań fizykochemicznych próbek wód, które pobrano $\mathrm{z}$ ujęć i źródeł w rejonie Buska-Zdroju, Solca-Zdroju i Kazimierzy Wielkiej (ryc. 2), stwierdzono różnice w zawartości jonów głównych. Potwierdzono zależność typu chemicznego wód od litologii poziomu wodonośnego, z którego wypływają i względem którego wykazują podobieństwo składu chemicznego. Wyniki obliczeń specjacyjnych umożliwiły określenie rzeczywistych form występowania poszczególnych składników wód siarczkowych badanego rejonu. W wodach tych siarka dwuwartościowa występuje przeważnie w formie $\mathrm{HS}^{-}$i $\mathrm{H}_{2} \mathrm{~S}$, a siarka sześciowartościowa $\mathrm{w}$ formie $\mathrm{SO}_{4}{ }^{2-}$, $\mathrm{NaSO}_{4}^{-}, \mathrm{MgSO}_{4}$ oraz $\mathrm{CaSO}_{4}$. Szczególnie istotna jest forma występowania składników mineralnych w wodach leczniczych, gdyż często decyduje ona o ich przyswajaniu przez organizm człowieka.

Przeprowadzone modelowanie hydrogeochemiczne umożliwiło określenie stanu nasycenia wód podziemnych względem wybranych minerałów obecnych w skałach zbiornikowych. Stwierdzono, że wszystkie analizowane wody siarczkowe są przesycone względem muskowitu, kaolinitu i pirytu. Wody poziomu kredowego wykazują ponadto przesycenie względem kwarcu, natomiast wody wypływające $\mathrm{z}$ utworów neogenu - względem kalcytu, kwarcu i chalcedonu. Wody poziomu jurajskiego są przesycone jonami węglanowymi. Uzyskane wyniki są zbliżone do wcześniejszych wyników badań innych autorów.

Autorki składają podziękowania Recenzentom - prof. dr hab. inż. Wojciechowi Ciężkowskiemu oraz dr hab. Marzenie Szostakiewicz-Hołowni za cenne uwagi oraz wnikliwą i merytoryczną opinię dotyczącą przedstawionych wyników badań. Badania wykonano $\mathrm{w}$ ramach działalności statutowej PIG-PIB, zadanie numer 61.8205.1702.00.0

\section{LITERATURA}

APPELO C.A.J., POSTMA D. 2005 - Geochemistry, groundwater and pollution, $2^{\text {nd }}$ edition. A.A. Balkema Publishers, CRC Press, Leiden. BZOWSKA G., KRZYKAWSKI T., RÓŻKOWSKI J. 2011 - Skład mineralny utworów neogenu oraz kredy i formujący się w nich chemizm wód podziemnych (w obszarze krasowym niecki nidziańskiej). Materiały 45. Sympozjum Speleologicznego, Ojców 20-23.10.2011 r., Kraków: 45-46.

CHOWANIEC J., ZUBER A., CIĘŻKOWSKI W. 2007 - Prowincja karpacka. Wody mineralne. [W:] Paczyński B., Sadurski A. (red.), Hydrogeologia regionalna Polski, t. 2: 83-86.

CHOWANIEC J., GĄGULSKI T., GORCZYCA G. 2015 - Chemizm niezagospodarowanych wód termalnych rejonu Buska-Zdroju i Solca-Zdroju. Prz. Geol., 63 (10/1): 645-651.

DOBRZYŃSKI D., KMIECIK E., WĄTOR K. 2018 - Potencjał utleniająco-redukcyjny - informatywny i niewykorzystany wskaźnik jakości wód leczniczych i mineralnych. Acta Balneol., 15 (4): 233-238.

DOWGIAŁŁO J., KLECZKOWSKI A.S., MACIOSZCZYK T., RÓŻKOWSKI A. (red.) 2002 - Słownik hydrogeologiczny. Państw. Inst. Geol.

GAŁA I. 2011 - Wstępne rozpoznanie i charakterystyka siarczkowych wód termalnych w otworze Busko C-1. Zrównoważony Rozwój, 1-2: 339-348.

GAŁA I. 2012 - Modelowanie hydrogeochemiczne formowania sie składu chemicznego wód siarczkowych rejonu Buska-Zdroju i Solca-Zdroju. Arch. Zakł. Oddz. Świętokrz. Państw Inst. Geol.-PIB, Kielce, nr inw. 2083,

GAŁA I. 2013 - Charakterystyka hydrochemiczna siarczkowych wód termalnych w otworze Busko C-1. Tech. Poszuk. Geol., Geotermia, Zrównoważony Rozwój, 2: 117-126.

GĄGULSKI T., CHOWANIEC J., GORCZYCA G., OPERACZ T., TOTT M., PATORSKI R., FELTER A. 2018 - Dokumentacja hydrogeologiczna ustalająca zasoby dyspozycyjne wód leczniczych, siarczkowych w rejonie Buska-Zdroju i Solca-Zdroju, pow. buski i pińczowski, woj. świętokrzyskie, zlewnia rzeki Nidy i Wisły, region wodny Górnej Wisły. Nar. Arch. Geol. Państw. Inst. Geol.-PIB, Warszawa, nr inw. $7317 / 2019$

LIPIEC I. 2009 - Wstępna analiza stabilności składników chemicznych i ocena trendów zmian jakości wód leczniczych Solca-Zdroju. Biul. Państw. Inst. Geol., 436: 323-328. 
LIPIEC I. 2015 - Skład chemiczny wód ze źródeł i z szybów rejonu Ponidzia. Biul. Państw. Inst. Geol., 462: 153-162.

LIPIEC I. 2017a - Assessment of hydrogeochemical equilibrium in the sulphurous water - rock environment in the Solec-Zdrój area. Procedia Earth and Planet. Sci., 17: 225-228.

LIPIEC I. 2017b - Analiza hydrogeochemiczna wód siarczkowych obszaru Niecki Nidziańskiej na podstawie badań ich naturalnych wypływów. Prz. Geol., 65, (11/1): 989-994.

LIPIEC I. 2019 - Analiza zmienności składu chemicznego wód siarczkowych rejonu Buska-Zdroju i Solca-Zdroju w układzie czasowo-przestrzennym. Rozpr. doktorska. Arch. Państw. Inst. Geol.-PIB, Warszawa. LIPIEC I., RUSINIAK P. 2020 - Stability assessment of sulphur (II) compounds in medicinal water from B-8b Michał intake in Busko-Zdrój. Bull. Geography. Physical Geogr. Ser., 18: 17-23.

LIPIEC I., WIKTOROWICZ B. 2015a - Charakterystyka hydrogeochemiczna wód siarczkowych rejonu Solca-Zdroju. Prz. Geol., 63 (10/2): 908-911.

LIPIEC I., WIKTOROWICZ B. 2015b - Lecznicze wody siarczkowe Ponidzia. Biul. Państw. Inst. Geol., 462: 171-178.

LISIK R. 2010 - Lecznicze wody siarczkowe rejonu Pińczów-Busko Zdrój-Kazimierza Wielka. [W:] Lisik R. (red.), Wody siarczkowe w rejonie Buska Zdroju. Wyd. XYZ, Kielce: 23-42.

LISIK R., SZCZEPAŃSKI A. 2014 - Siarczkowe wody lecznicze w części zapadliska przedkarpackiego. Wyd. Fundacja POSTERIS, Kielce.

LISIK R., SZCZEPAŃSKI A. 2018 - Siarczkowe wody lecznicze w części zapadliska przedkarpackiego, część 2, 2014-2018. Wyd. Wojciech Ciaggło Studio DTP, Kielce.

ŁYCZEWSKA J. 1975 - Zarys budowy geologicznej pasma wójczo-pińczowskiego. Biul. Inst. Geol., 283: 151-183.

MACIOSZCZYK A. 2006 - Podstawy hydrogeologii stosowanej. Wyd. PWN, Warszawa.

MACIOSZCZYK A., DOBRZYŃSKI D. 2002 - Hydrogeochemia strefy aktywnej wymiany wód podziemnych. Wyd. PWN, Warszawa.

MERKEL B., SPERLING B. 1996 - Hydrogeochemische Stoffsyteme, Teil 1, DVWK Schriften 110, Deutscher Verband für Wasser und Kulturbau e.V., Bonn.

MIGASZEWSKI A. 2010 - Analiza hydrogeologiczna wód siarkowodorowych ze źródeł i studni kopanej. [W:] Lisik R. (red.), Wody siarczkowe w rejonie Buska-Zdroju. Wyd. XYZ, Kielce: 295-333.

MIGASZEWSKI A. 2013 - Czynniki kształtujące chemizm wód podziemnych w południowej cześci Niecki Nidziańskiej. Praca doktorska. Arch. Wydz. Geologii, Geofizyki i Ochrony ŚrodowiskaAGH, Biblioteka Główna, Kraków, sygn. R.10731.

PARKHURST D.L., APPELO C.A.J. 2013 - Description of input and examples for PHREEQC version 3: a computer program for speciation, batch-reaction, one-dimensional transport, and inverse geochemical calculations. U.S. Geological Survey, Denver, Colorado.

PRAŻAK J. 2010 - Szkic warunków paleohydrogeologicznych w procesie kształtowania się składu chemicznego wód mineralnych w rejonie Buska-Zdroju. [W:] Lisik R. (red.), Wody siarczkowe w rejonie Buska Zdroju. Wyd. XYZ, Kielce: 245-266.
RÓŻKOWSKI J., RÓŻKOWSKI A. 2010 - Pochodzenie mineralizacji wód siarczkowych Buska - ich paleogeneza. [W:] Lisik R. (red.), Wody siarczkowe w rejonie Buska Zdroju. Wyd. XYZ, Kielce: 151-174.

RÓŻKOWSKI J., ANDREJCZUK V., PULINA M., CHWALIK A. 2006 - Geogeniczne uwarunkowania formowania się składu chemicznego wód podziemnych w obszarze występowania krasu gipsowego Niecki Nidziańskiej. Problemy Ekologii Krajobrazu, 16: 391-399.

RÓŻKOWSKI J., JÓŹWIAK K., ANDREJCZUK V. 2011 - Chemizm wód podziemnych serii gipsonośnej badenu w północnej części zapadliska przedkarpackiego. Biul. Państw. Inst. Geol., 445: 573-582.

SELINUS O., ALLOWAY B., CENTENO J.A., FINKELMAN R.B., FUGE R., LINDH U., SMEDLEY P. 2005 - Essentials of Medical Geology. Impact of the natural environment on public health, Elsevier Inc., Amsterdam, 812.

STUPNICKA E. 2007 - Geologia regionalna Polski. Wyd. Uniw. Warsz. 2007.

SZCZEPAŃSKI A., PORWISZ B. 2007 - Lecznicze wody siarczkowe z miejscowości Las Winiarski k. Buska-Zdroju. [W:] III Konferencja Naukowo-Techniczna: Geologia stosowana i ochrona środowiska, Suchedniów, 15.06.2007 r. Wyd. PPU DCF, Kielce: 97-112.

TOMASZEWSKA B. 2008 - Prognozowanie Kolmatacji Instalacji geotermalnych metodą modelowania geochemicznego. Gosp. Sur. Miner., $24(2 / 3): 399-407$.

USTAWA z dnia 9 czerwca 2011 r. Prawo geologiczne i górnicze. Dz. U. z 2020 r. poz. 1064 , z późn. zm.

WÁTOR K. 2013 - Przestrzenno-czasowa analiza zmienności składu chemicznego wód leczniczych rejonu Buska-Zdroju. Rozpr. doktorska. Arch. AGH, Biblioteka Główna, Kraków, sygn. R.10753.

WATOR K. 2015 - Ocena leczniczego charakteru wód z wykorzystaniem niepewności pomiaru w wodach uzdrowiska Busko-Zdrój. Tech. Poszukiwań Geologicznych, Geotermia, Zrównoważony Rozwój, 2: 79-88.

WATOR K., KMIECIK E. 2015 - Analiza trendów zmian składu chemicznego wód leczniczych z ujęcia B-13 w Busku-Zdroju z wykorzystaniem programu GWSDAT. Prz. Geol., 63 (10/2): 1125-1130.

WĄTOR K., KMIECIK E., LIPIEC I. 2019 - The use of principal component analysis for the assessment of the spatial variability of curative waters from the Busko-Zdrój and Solec-Zdrój region (Poland) - preliminary results. Water Supply, 19 (4): 1137-1143.

WHITFIELD M. 1974 - Termodynamics limitation on the use of the platinum electrode in Eh measurements. Limnology and Oceanography, 19: $857-865$.

WIKTOROWICZ B. 2016 - Wody geotermalne rejonu Kazimierzy Wielkiej i możliwości ich zagospodarowania. Tech. Poszukiwań Geologicznych, Geotermia, Zrównoważony Rozwój, 2: 45-54.

WIKTOROWICZ B., LIPIEC I., KOS M., MŁYŃCZAK T. 2015 - Perspektywy i możliwości wykorzystania siarczkowych wód termalnych w rejonie Kazimierzy Wielkiej. Prz. Geol., 63 (10/2): 1131-1134.

WITCZAK S., ŚWIĄDER A. 2010 - Analiza składników swoistych wód siarczkowych rejonu Buska Zdroju. [W:] Lisik R. (red.), Wody siarczkowe w rejonie Buska Zdroju. Wyd. XYZ, Kielce: 245-266.

Praca wpłyneła do redakcji 28.04.2021 r. Akceptowano do druku 9.07.2021 r. 